Magdalena ZowczaK

Uniwersytet Warszawski

\title{
Obrazki z terenu albo oniryczne reminiscencje Laboratoriów etnograficznych
}

Z powitania, jakie wygłosiła dla mojego świeżo upieczonego studenckiego rocznika Anna Zadrożyńska, zapamiętałam zdanie, które - przynajmniej, jeśli chodzi o moje studia - okazało się prorocze. „Życzę państwu - powiedziała żebyście przeżyli prawdziwą naukową przygodę". Trafiła w sedno - tym życzeniem pomogła mi otworzyć się na nowe doświadczenia, a może też je trochę zaprojektowała. Przebiła nim zniechęcenie i wycofywanie się z rzeczywistości, wywołane szkolną opresją i udręką nieudanych egzaminów na wymarzoną Akademię Sztuk Pięknych. Było to zaproszenie do rozmowy.

Był rok 1974, epoka, kiedy „antropologia” nikomu się jeszcze nie śniła, a „etnologia" uchodziła za burżuazyjny wymysł. Postanowiłam zdawać na historię sztuki, ale usłyszawszy, jak trudno się tam dostać, przekreśliłam w formularzu ten kierunek, wpisując ponad nim „etnografia”. „To gdzie pani właściwie chciała zdawać?" - zapytał prowokacyjnie Ludwik Stomma, członek komisji egzaminacyjnej. Nosiłam się jeszcze przez czas jakiś z zamiarem przeniesienia na historię sztuki, chodziłam tam na wykłady. Nie pociągały mnie ówczesne standardowe praktyki dokumentacji etnograficznej, wzorowane na Kulturze ludowej Słowian Kazimierza Moszyńskiego, czy odpytywania mieszkańców wsi ściśle według kwestionariusza. Przekonały mnie jednak do studiowania etnografii (ówczesnej nauki pomocniczej historii) badania terenowe mojej grupy laboratoryjnej, czyli ludzie i rozmowy, spotkania w miejscach nasycanych przez nie znaczeniem, w specyficznym praesens ethnographicum. Ulotne chwile, kiedy odsłania się nagle sens, zyskuje się poczucie zrozumienia. Rozbłyskują i nikną, i tylko poezja i fenomenologia umożliwiają ich uchwycenie w sieci słów. Miałam wrażenie, że 
rozprasza się mgła, która mnie osaczała, odsłaniając namacalny konkret, a jednocześnie zyskuję podmiotowość, chociaż wówczas nie potrafiłam tak określić tego, co się działo.

Co pozostaje z tych ulotnych wrażeń poza inspiracją do mniej czy bardziej udanych publikacji? Czasami pod wpływem jakiegoś drobnego bodźca uruchamia się strumień wspomnień - obrazów, rozświetla się zarys twarzy, powracają dźwięki, zapachy, smaki.

Prof. Anna Zadrożyńska była osobą bardzo bezpośrednią i miała dar dostarczania nam trzeźwych wskazówek. Zapamiętałam jej opowiadanie o jej własnych badaniach do pracy magisterskiej (temat był wówczas zazwyczaj formułowany przez promotora). Wysłano ją, żeby zbadała strój ludowy w regionie, gdzie - jak się okazało - stroju ludowego nie było. Napisała więc pracę o przyczynach braku stroju ludowego w tym regionie. Później tę taktykę otwartości na wszystko, co niesie życie (bliską temu, co dziś nazywamy refleksyjnością) przekazywała studentom. Na przykład Piotrowi Kędziorkowi, obecnemu redaktorowi radiowej Dwójki, który wrócił rozczarowany z badań terenowych na wsi. „Ale co tam się wydarzyło?" - dopytywała pani profesor. "Nic, chłopi ciągle narzekali”. "No to napisz o tym" - zaproponowała. I tak powstała praca magisterska o chłopskim narzekaniu.

Laboratorium etnograficzne, dwuletni cykl badań zespołowych - nauki warsztatu, wprowadzono do programu studiów około roku 1973 i do dziś pozostaje znakiem firmowym warszawskiej etnologii. $\mathrm{O}$ ile mi wiadomo, autorem pomysłu był wspomniany Ludwik Stomma. Chociaż, jako strukturalista z historycznym backgroundem, nie traktował naszych materiałów jako pełnowartościowych źródeł, lecz raczej szukał w nich potwierdzenia swoich pomysłów, ogólna idea okazała się trwała.

Ważne jest, jak w każdej praktyce, doświadczenie inicjujące, którego nie sposób zaprogramować: pierwsza rozmowa, nastawienie rozmówcy, styl komunikacji, więź, która się tworzy (lub nie) w rozmowie. Inicjację terenową przeżyłam w grupie starszych kolegów, dołączona do Laboratorium etnograficznego, które prowadził Zbigniew Benedyktowicz, późniejszy wieloletni redaktor naczelny "Kontekstów". Nie pamiętam, jaki był temat grupy Zbyszka, ale z pewnością był związany z prawosławiem. Na badania mojej własnej, pierwszorocznej grupy laboratoryjnej, nie dotarłam z powodu choroby. A wybierałam starannie (grupy mają program autorski i zawsze były co najmniej dwie), poszukując publikacji osób prowadzących. Spodobały mi się artykuły Jacka Olędzkiego o wotach, odkryte w „Polskiej Sztuce Ludowej” (matce „Kontekstów”). Tematem jego Laboratorium były zdarzenia cudowne. To mnie zainteresowało.

Tak znalazłam się w Chilmonach pod Dąbrową Białostocką, z Jackowym kwestionariuszem dotyczącym zdarzeń cudownych. Spaliśmy ściśnięci jak szprotki w świeżo wyremontowanej szkole, na rozłożonych na podłodze materacach. Byłam najmłodsza, więc przydzielono mi miejsce przy kaflowym piecu, gdzie spałam z podkurczonymi nogami - bo trochę ograniczał moją przestrzeń życiową. Nic chyba w tej szkole nie było poza stołem i ławami. Budził nas 
chłód, myliśmy się na podwórku przy studni. Powtarzałam w pamięci kwestionariusz przez całą nieprzespaną noc, zastanawiając się, jak sformułować bezpośrednie pytania.

Była wczesna wiosna, jeszcze bez liści, w odcieniach brunatnych pól i zieleni wschodzącej oziminy. Dzień był szary, pochmurny i niezbyt zachęcający. To było trochę jak skok do wody na głowę: wejść do zagrody, przekroczyć próg chaty. Wewnątrz, w bladej poświacie ćmiącej żarówki, tęga gospodyni zabierała się właśnie do mycia podłogi. Już chciałam się wycofać, umówić "na później” (to taki defensywny eufemizm), ale kiedy wymusiła wyznanie, o co mi chodzi, zachęciła mnie, wyraźnie zaciekawiona. Rozmawiałyśmy o cudach przez ponad godzinę, gospodyni cały czas na kolanach, w trakcie mycia podłogi - ja na ławie pod ścianą, notując w zeszycie. Od czasu do czasu tylko podnosiła głowę znad szmaty do podłogi, zastanawiając się nad odpowiedzią. Ale mówiła swobodnie i nie było w naszym spotkaniu niczego wymuszonego ani też sztucznego. Byłam oswojona z wsią, bywałam na żniwach u rodziny i u gospodarzy na Podhalu, więc religijny wiejski dyskurs nie był mi obcy. A jednak w wielu rozmowach w Chilmonach i okolicy język, a także ikonografia obrazów na ścianach chat, były dla mnie (wychowanej w centralnej Polsce) nowe i niezwykłe. Przenosiły w inną, metafizyczną przestrzeń. Właśnie wówczas, dopytując o ikony, usłyszałam po raz pierwszy nazwę Neopalimaja Kupina - Krzew Gorejący, i zapamiętałam ją, chociaż jej sens jako symbolu maryjnego, który łączy oba biblijne Testamenty, poznałam znacznie później.

Wracałyśmy miedzami z Alinką Całą, uczestniczką grupy. Niosłam magnetofon Unitry (polska produkcja na licencji Thomsona) przewieszony przez ramię, prezent gwiazdkowy od rodziców, a z magnetofonu śpiewał nam w rytm wędrówki Bob Dylan; Alina była (i pozostała) jego fanką, to była jej kaseta. Ja miałam głównie Poloneza Es-dur op. 22 Chopina w jakimś profesjonalnym wykonaniu, które nagrałam z radia; wzbudzało to uśmiechy towarzystwa, ale do dziś wywołuje on w mojej pamięci obrazy tamtej wczesnej wiosny i wędrówki wśród płaskich, rozległych pól Podlasia.

Od tamtego czasu właściwie stale towarzyszą moim badaniom podobne emocje. Na przemian dojmująca samotność, narastające napięcie w poczuciu, że czas ucieka, trzeba wreszcie coś zrobić, przemóc się, dopóki nie uda się nawiązać kontaktu, spotkać z osobą, z którą przez chwilę połączyło mnie zainteresowanie jakąś konkretną sprawą. A potem ulga, ale z uczuciem zmęczenia i pewnego wyczerpania, ponieważ godzinna, dwugodzinna, a czasem i dłuższa koncentracja uwagi na każdym zdaniu, na każdym wypowiedzianym słowie i geście rozmówcy, zawsze łączy się z pewnym wysiłkiem. Zdarza się, że świadomość ucieka, przerywa ją chwilowy sen, nagła wizja, wplatające się w monolog rozmówczyni. W długiej rozmowie z nieznajomą osobą często odczuwa się rzeczy, których powtórzyć ani odtworzyć nie sposób. Jeśli przydarza się dobra rozmowa z człowiekiem, którego nigdy więcej być może się już nie spotka, czas staje w miejscu. Pamiętam takie chwile, w łagodnym świetle popołudnia, wyzłacającym wnętrze izby czy pokoju, przy kuchennym stole, nad wypieczonym świeżo chlebem, 
kiedy ciszę mąciło już tylko tykanie zegara i brzęk much. Mistyczny praesens ethnograpicum, czas podzielanego doświadczenia - ulotny czas spotkania, jak to interpretowała Kirsten Hastrup, dystansując się wobec kolonialnego znaczenia tego terminu (Hastrup 2008: 26).

Poza ikoną Krzewu Gorejącego odkryłam w okolicach Chilmonów inne frapujące przedstawienie maryjne, które patronowało później przez lata moim terenowym poszukiwaniom. „To Matka Boska Polska, co dusze z czyśćca wyprowadza" - wyjaśnił mi gospodarz. Niestety nie miałam jeszcze wówczas aparatu fotograficznego i nie pamiętam, jak wyglądał obraz. Zapewne była to jakaś wersja przedstawienia Matki Boskiej Różańcowej albo Szkaplerznej z duszami $\mathrm{w}$ płomieniach czyśćcowych, ukazanymi w dolnym rejestrze. Niektóre z nich anioły wyciągają z płomieni, a Maria z Dzieciątkiem, i jednym ze wspomnianych narzędzi ewakuacji, ukazana jest w górze, na obłoku. Przez wiele lat sądziłam, że dosłowność owego wyciągania była swoistą nadinterpretacją rozmówcy, wykreowaną w kontekście ludowych modlitw. Aż w przedsionku kościoła św. Anny w Wejherowie nagle zauważyłam obraz, który przedstawiał dokładnie to, o czym powiedział mój dawny rozmówca, a co zbiega się z sensem ludowych modlitw maryjnych. Ich treść można sprowadzić do tego, że duszyczka, pojedyncza ludzka animula, skierowana surowym boskim wyrokiem na drogę do piekła, woła w rozpaczy pomocy Matki Boskiej, która ją przygarnia i prowadzi do nieba. Na wejherowskim obrazie to sama Matka Boska podaje rękę duszy wydobywającej się z płomieni.

Jacek Olędzki, jako pierwszy z wykładowców w ówczesnej Katedrze Etnografii (choć nigdy nie był jej pracownikiem), zażądał od nas nagrywania rozmów na taśmie magnetofonowej. Jednocześnie tropił i wyszydzał każdą analogię z praktykami służb specjalnych, co $\mathrm{w}$ drugiej połowie lat 70. miało szczególne znaczenie. (Pewien etnograf $\mathrm{w}$ artykule na temat sposobów prowadzenia wywiadów powoływał się na podręcznik kryminalistyki.) Takie terminy, jak „,wywiad”, a zwłaszcza „informator", były na Jacka zajęciach zakazane. Dlatego odkryty w bibliotece tekst Gadamera, który zapamiętałam jako Zaproszenie do rozmowy (faktycznie tytuł brzmiał inaczej: Niezdolność do rozmowy, Gadamer 1980), był dla mnie olśnieniem, dyskursywną formą przedstawienia modelu praktykowanego już wcześniej dialogu. Dlatego też nigdy nie zdarzyło mi się nagrywać rozmówców z ukrycia, bez ich zgody.

\section{Biesiada, prynuka i chleb}

W Chilmonach towarzyszyła nam osoba spoza Uniwersytetu, Amerykanka, chyba żona pracownika ambasady czy służb konsularnych. Słabo znała polski, ale obserwowała nas i prowadziła dziennik. Panowie dobrali się do niego pod jej nieobecność i odkryli notatki o osobliwym polskim zwyczaju wieczornego picia alkoholu z jednego kubka. Emaliowane metalowe kubki wraz z grzałką należały wówczas (obok magnetofonu) do niezbędnego zestawu badacza terenowego. 
Często poobtłukiwane, brunatne od zaparzanej z listków herbaty yunan (torebek herbacianych też jeszcze nie było) dyndały dumnie przytroczone do plecaków. Takie kubki były, zwłaszcza na wsi, w powszechnym użyciu. Przypomina mi to anegdotę z czasów, kiedy już sama po raz pierwszy opiekowałam się grupą laboratoryjną. Prowadziliśmy badania w wioskach nadwiślańskich $\mathrm{w}$ ramach rządowego Projektu Wisła, zwanego ironicznie „Akcją Wisła”. (Oficjalnym prowadzącym był Marian Pokropek, ówczesny docent, ja - świeżo zatrudniona w Katedrze $\mathrm{w}$ ramach tejże akcji $\mathrm{W}$, debiutantka - zostałam mu dodana do pomocy.) Jeden ze studentów trafił do domu samotnej staruszki. Był upał, więc, porozmawiawszy z nią chwilę, poprosił o wodę. Przyniosła mu w poobłłukiwanym kubku, którego brzeg czernił się podrdzewiałym metalem; emalia ocalała tylko w jednym miejscu. Julkowi bardzo chciało się pić, więc ostrożnie przywarł wargami do jedynego jasnego, bezpiecznego miejsca. Staruszka stała nad nim, uśmiechając się dobrotliwie bezzębnymi ustami, a kiedy oddał jej kubek, wysepleniła: „Ale tez pan uobzydliwy, zupełnie jak ja. Ja tez zawse pije tylko z tego miejsca".

Na wschodzie przywykłam nie odmawiać poczęstunku, chociażby to było bardzo uciążliwe. W przeciwnym razie trudno było nawiązać kontakt, a gospodarze chyba $\mathrm{w}$ ten sposób zyskiwali poczucie bezpieczeństwa, obserwując czujnie i z zaciekawieniem każdy gest gościa, każdy szczegół jego zachowania. Obowiązywała niepisana zasada, żeby „zjadać do czysta” (podobnie zresztą było i w mojej rodzinie). Trafne określenie praktyki utożsamianej z gościnnością znalazłam w listach Mieczysława Dowojny-Sylwestrowicza, drobnego szlachcica ze Żmudzi, w jego korespondencji z Janem Karłowiczem: „Niczego tam nie brakowało, chyba tylko przymusu". Co prawda w chłopskich domach wymawianie się nie było obowiązkowe, miało raczej charakter drobnoszlacheckich konwenansów. Osławiona prynuka, swoista dramaturgia słowiańskiej gościnności, to kontredans powtarzanych na zmianę natrętnych zachęt, nakładania siłą na talerz i wymawiania się - to ostatnie zwłaszcza w przypadku dziewcząt. Można w ten sposób „zapaść” albo (zwłaszcza) „zapić” gościa na śmierć, jak o tym prawią staropolskie pamiętniki.

W Polsce wschodniej, w ówczesnych województwach białostockim, chełmskim czy przemyskim, gościnność gospodarzy wobec nas, studentów, czy mnie, kiedy prowadziłam już badania na własną rękę, trudna jest do opisania i chyba już dziś nieosiągalna. Traktowali nas, nieznajomych, jak własne dzieci, których zazwyczaj nie widzieli od lat, bo wyjechały do miasta i tam już pozostały. Wyludnione wioski i opuszczone chaty miały jednak na tych terenach również inne, nieznane mi wówczas znaczenie. Niewiele jeszcze wiedziałam o akcji Wisła, a i nasi rozmówcy o tym nie opowiadali. Pewnego razu, gdzieś w okolicach Dubienki, trafiłam do takiej wymarłej wioski, weszłam we wrota zniszczonej cerkwi. Pełna śmieci, służyła najwyraźniej za schronienie przygodnym biesiadnikom i ptakom, gnieżdżącym się gdzieś u stropu. Przez rozpadającą się kopułę przenikał błękit nieba, a z resztek polichromii odczytałam (w każdym razie tak to pamiętam) pierwsze zdania Janowej Ewangelii: „Na początku było Słowo...". W jednej z chat znalazłam porzucony modlitewnik, a w nim 
dewocyjny obrazek przedstawiający Matkę Boską Skępską w otoczeniu pociągniętych pozłotą wotów: schematycznych rączek, nóżek i serc. W czasie naszych wypraw dowiedziałam się od rozmówców o paleniu cerkwi prawosławnych przez wojsko polskie w latach trzydziestych, o powojennym obozie koncentracyjnym w Jaworznie, wreszcie na Wileńszczyźnie - o rzeziach w Glinciszkach i Dubinkach. Nie dowiedziałam się natomiast o udziale mieszkańców w Holocauście; najwyraźniej ten wątek historii lokalnej zbyt drastycznie naruszał wizerunek własny. Jedynie wszechobecne opowieści o ukrytym gdzieś w okolicy żydowskim złocie budziły mój niepokój.

Gościnność naszych gospodarzy wiązała się także z ich poczuciem godności osobistej: im biedniejszy dom, tym większym dyshonorem była odmowa gościa. Kiedy tłumaczyłam się, że nie jestem głodna, łzy stawały w oczach gospodyni i prosiła, żeby nią nie gardzić. Otwartym sercom i spiżarniom towarzyszyło specyficzne doświadczenie otwartej wiejskiej przestrzeni, w której droga czasem przebiegała przez podwórze. Wydawało się, że gospodarzom to zupełnie nie przeszkadza, przeciwnie: jakby dzięki temu zyskiwali poczucie kontroli nad lokalną rzeczywistością. Obserwowali, kto się pojawiał we wsi, czasem zaczepili nieznajomego, pogawędzili z dawno niewidzianym sąsiadem. Płoty służyły głównie jako zagrody dla zwierząt. Przyzwyczaiłam się do tego i nie dostrzegałam $w$ tej otwartości niczego nadzwyczajnego, aż do moich duńskich wakacji, kiedy trzy lata później odwiedziłam Jutlandię. Zdumiały mnie wysiłki przyjaciół, którzy szukali na pustym morskim wybrzeżu możliwości dotarcia do celu wśród tabliczek PRIVATE, aby przypadkiem nawet czubkiem stopy nie naruszyć czyjejś własności. Letnie domki, rozrzucone w dużych od siebie odległościach, były wynajmowane w sezonie wakacyjnym. Nie było żadnych ogrodzeń, a tabliczka pojawiała się nagle na ścieżce - i to wystarczyło. Gospodarz tak zastrzeżonego terytorium, widząc $z$ daleka intruza, wybiegał przed dom i wznosił gniewne okrzyki, z kategorycznym żądaniem wycofania się natychmiast tą samą drogą.

Jak wspomniałam, prynuka gospodarzy bywała niebezpieczna; spróbować trzeba było wszystkiego, a częstowano nas rozmaitymi lokalnymi specjałami. Szczególnego rarytasu popróbowałam w Wodoktach (sienkiewiczowskich, chociaż raczej pokołchozowych). Wybrałam się z Wilna do Poniewieża, aby stamtąd autobusem dotrzeć w to słynne miejsce, gdzie zatrzymała się już moja grupa. Nie pamiętam, dlaczego nie pojechałam jak zwykle razem ze studentami. W Poniewieżu okazało się, że autobus do Wodoktów tego dnia z jakichś powodów nie pojedzie, więc wyruszyłam pieszo, licząc na okazję. Rzeczywiście, kawałek podwiozła mnie ciężarówka, ale potem kierowca musiał skręcić w inną trasę i powędrowałam pustą drogą. Trwało to cały dzień (według współczesnych map Google odległość z Poniewieża do Wodoktów, zależnie od trasy, wynosi 30-42km), szosa biegła w pełnym słońcu, po bokach nie było drzew, żeby się schronić przed żarem. Latem dni na Żmudzi ciągną się bardzo długo. W pewnym momencie zobaczyłam przed sobą dwa ptaki, czarnego i białego, które przez jakiś czas poruszały się wzdłuż mojej drogi, jakby mnie prowadziły. Mam je do dziś przed oczami, niczym opiekuńcze duchy. 
W Wodoktach gospodarzom, u których mieszkali studenci, ocieliła się krowa. Pierwsze mleko po ocieleniu nazywa się siarą; zostałam więc ugoszczona smakołykiem w postaci zapieczonej siary, niezwykle tłustej i, jak sądzę, niezwykle ciężkostrawnej. Mój żołądek, pusty po dniu wędrowania, zniósł to jednak bez problemu (w przeciwieństwie do żołądków niektórych studentów).

O ile samogony domowe, po rojstach pędzone, były bezpieczne, a kiedyś nawet taki trunek błyskawicznie wyprowadził mnie z grypy, prawdziwy niepokój wzbudziła we mnie tak zwana kropka, czyli płynny eter, którym mnie poczęstowano na Łemkowszczyźnie. Opowiadano, że traciło się od niego wzrok, ale zdaje się, że możliwe były innego rodzaju zagrożenia, np. perforacja żołądka. Ostatnio odkryłam artykuł Adriana Zandberga na temat dziejów kropki, czyli eteromanii, w Polsce międzywojennej; na szczęście nie doznałam opisywanych powszechnie efektów w postaci stanu ekscytacji, podniecenia, euforii, który potem często "przechodzi w fazę szału, następnie zamroczenia i snu z halucynacjami" (Zandberg 2012).

Czasem jednak trafiały się niebywałe przysmaki. W Wodoktach, w drewnianym dworku, starsza pani, polska dziedziczka, która życie przepracowała w kołchozie, poczęstowała mnie ogórkami z miodem. Po raz pierwszy spróbowałam takiego zestawu, którego smaku niestety nie da się łatwo odtworzyć: ogórki były świeżo zerwane w ogródku, a miód z pobliskiej pasieki.

Wiele lat później, w Murafie na Podolu, zaszłam do domu starszej kobiety, która dość długo ze mną rozmawiała, a potem zaprosiła mnie do swojego posiłku. Z powodu obrzękniętych nóg nie mogła już chodzić do sklepu ani do kościoła, dzieci zaopatrywały ją w żywność. Kiedy skończyłyśmy jeść, schyliła się z trudem, żeby podnieść okruszek chleba, więc ruszyłam do pomocy. Wzrok miała bardzo dobry; wskazywała mi okruchy końcem laski, a ja wędrowałam przez kwadrans na kolanach po całej izbie. W myślach wyświetlały mi się strofy: „Do kraju tego, gdzie kruszynę chleba / Podnoszą z ziemi przez uszanowanie / Dla darów nieba, /Tęskno mi, Panie". Nie pominęłyśmy ani jednego okruszka. (Nie pomijam do dzisiaj.)

\section{Z życia roślin, ludzi i zwierząt}

W stanie wojennym, zdeterminowana, żeby zgromadzić trochę materiałów do planowanej pracy o bohaterze wsi, umówiłam się z przyjaciółką na badania terenowe pod Kolbuszową. Nie miałyśmy specjalnych preferencji w kwestii miejsca naszych badań etnograficznych, więc dokonałyśmy wyboru, jadąc na chybił-trafił palcem po mapie. Nagabywane nieprzyjemnie przez służbowych SOK-istów, dotarłyśmy w końcu do wyznaczonej w ten przy padkowy sposób wsi i udało nam się znaleźć noclegi u miłej gospodyni. Szybko się okazało, że aktualną bohaterką rozmów tej społeczności jest azalia, której okazały krzew, dziko rosnący w pobliskim lesie, co roku okrywa się żółtymi pachnącymi kwiatami. Rosła tam „od zawsze". Wielu próbowało przeszczepić sobie jej gałązkę do domowego ogrodu, 
ale nigdy żadna się nie przyjęła. O tej azalii krążyło wiele opowieści, z których zapamiętałam najbardziej poruszającą. Mówiono, że jeśli ktoś zaśnie w jej cieniu, nigdy się już nie obudzi. Ten dziw natury stanowił zarazem państwową instytucję: mianowano dziką azalię pomnikiem przyrody. Następstwem tej nobilitacji był obowiązek ochrony przed niebezpieczeństwem, dlatego w stanie wojennym doglądały azalii konne patrole Milicji Obywatelskiej. To wywoływało szczególne poruszenie wśród mieszkańców, którzy w rozdrażnieniu mówili o niej „ta głupia azalia". (Dziś, jak mi podpowiada Internet, stała się lokalnym dobrem komercyjnym; daje zarobić gospodarstwu agroturystycznemu i patronuje rokrocznym zjazdom.)

Na Wileńszczyźnie, gdzieś w okolicach Niemenczyna, trafiłam pewnego letniego dnia do domku na skraju wioski, który wyglądał jak mały dworek. Otaczał go ogród pełen kwitnących lilii. Nigdy nie widziałam tylu ich odmian i kolorów na raz, istny rajski mikrokosmos o odurzającym zapachu, niesionym daleko przez wiatr. W dworku mieszkało małżeństwo w starszym wieku. Kobieta, która wyszła mi na spotkanie, miała całą twarz owiniętą chustą; tylko oczy spod niej wyglądały. Okazało się, że ma ostrą alergię, która nasila się zawsze, kiedy zakwitają jej ukochane lilie.

Pewnego razu nocowaliśmy w Bujwidzach, w stodole gospodarstwa mamy naszej zaprzyjaźnionej nauczycielki spod Wilna. Rankiem obudził mnie wesoły głos gospodyni, która przyniosła nam dzbanek świeżego mleka i chleb z własnego pieca - dary, których smaku i zapachu nigdy nie zapomnę. To ona zaśpiewała mi łałymkę, czyli kolędę życzącą - wiośniankę (bo na Wileńszczyźnie chodzenie po kolędzie bardziej było popularne wiosną niż zimą). Powtarzający się refren „Winszuję winem zielonym” oddziela zwrotki, które opowiadają o jaworze i ptakach, strząsających z niego perłową rosę i złote liście. Zbiera je dziewczyna i oddaje do złotnika:

Wy złotniki, wy komorniki, zróbcie dla mnie trzy radości. Pierwsza radość to srebrny kubek, druga radość złoty pierścionek, trzecia radość perłowy wianek. Srebrny kubeczek swatu daruneczek, złoty pierścionek lubemu daruję, perłowy wianek do ślubu szykuję.

Ta łałymka chyba dostarczyła inspiracji Gałczyńskiemu (niektóre jego wiersze z pewnością czerpały z folkloru), a jego nostalgiczny wiersz o winie zaśpiewał Marek Grechuta:

Nad oknem, na murze, a liście takie duże - zielone, zielone dzikie wino zielone. O każdej godzinie wiatr szumi w dzikim winie - zielone, zielone, dzikie wino zielone. Uroda, przyroda za nic byś jej nie oddał - zielone, zielone, dzikie wino zielone. Za siedmiu morzami napełni oczy łzami - zielone, zielone, dzikie wino zielone ${ }^{1}$.

\footnotetext{
${ }^{1}$ Fragment wiersza Konstantego Ildefonsa Gałczyńskiego Dzikie wino, z 1953 r.
} 
Szczególny zestaw dźwięków, jakie przywiozłam z badań, pochodzi z Murafy w obwodzie winnickim (Ukraina). Zamieszkałam, zgodnie z zarządzeniem proboszcza, w podominikańskim klasztorze, przekształconym w plebanię. Wykusze okienne w osiemnastowiecznych grubych murach ulubiły sobie jaskółki, wijąc w nich rokrocznie gniazda, ku utrapieniu proboszcza. Pięć razy w ciągu dnia z kościelnej wieży niosły się melodie tradycyjnych katolickich pieśni, za każdym razem innej. Za każdym razem dołączały też do nich dwa psy proboszcza: wielki owczarek wył barytonem, mały jego towarzysz - altem. Głosy jaskółek i psów łączyły się z melodiami kurantów w wielogłosową orkiestrę.

\section{Dziwaczne tematy i common sense}

Pewnego razu gdzieś na Podlasiu trafiłam do wioski, w której opowiadano mi o mieszkańcu dworku, ostatnim potomku starego rodu. Nie wiem, jak udało mu się powrócić w rodzinne pielesze w czasach PRL-u, dość że zamieszkiwał chylący się ku upadkowi dwór, a wieś lubiła o nim opowiadać. Był to samotny mężczyzna w średnim wieku, o którego nieudanych zalotach krążyły liczne prześmiewcze opowieści. Odgrywał najwyraźniej rolę lokalnego błazna, darzonego jednak swoistym szacunkiem, ze względu na wykształcenie i pańskie obyczaje. Postanowiłam wybrać się do niego na rozmowę o ludowych apokryfach. W koronach wysokich drzew, rosnących wzdłuż zarośniętej dworskiej alei, gnieździły się liczne wrony. Bałam się spojrzeć do góry, bo cała okolica była biała od ich odchodów. Wrzeszczały nad moją głową, jakby weszły w rolę gęsi kapitolińskich. Okazało się, że furtka prowadząca do dworu jest zamknięta. Zatrzymałam się więc przy niej i zawołałam gospodarza, przekrzykując wronie wrzaski. Po chwili wyjrzał zza drzwi. „Czy może mnie Pan wpuścić?! Chciałam porozmawiać! Jestem z Uniwersytetu Warszawskiego!” - wykrzyknęłam na koniec bez sensu, ale chciałam się jakoś przedstawić. „Nie szkodzi!” - odkrzyknął dowcipnie gospodarz. Rozmawialiśmy potem długo w zrujnowanym dworku, ale nie bardzo na temat, który mój rozmówca, skądinąd słusznie, uznał za dziwaczny. Zapamiętałam jedyną biblijną anegdotę, którą mi opowiedział. „Wie pani, dlaczego św. Piotr zdradził Pana Jezusa?” - zapytał z chytrym uśmiechem. Zamieniłam się w słuch. „Bo mu uzdrowił teściową!". Sprawdziłam (wówczas moja wiedza biblijna pozostawiała wiele do życzenia); faktycznie, wszystko się zgadza...

Poświęcaliśmy zwykle uwagę popularnym etymologiom, które świetnie wprowadzają w lokalną tradycję i dyskurs, w Herzfeldowski common sense porównawcze badanie zdrowego rozsądku (Herzfeld 2004). Używamy pewnych słów od dzieciństwa, nie zastanawiając się nad ich znaczeniem, które jest przekazywane bezpośrednio, w sieci rozmaitych językowych konotacji. Bywa to ciekawe zwłaszcza na pograniczach, gdzie krzyżują się języki. Polacy spod Wilna, pytani o znaczenie nazwy Niemenczyn, opowiadali, że pochodzi z czasów Napoleona (tradycja napoleońska była na Wileńszczyźnie w latach dziewięćdziesiątych 
bardzo popularna). Kiedy dotarł w te strony ze swoją armią, stanął na wzgórku i zapytał: "Czy to Niemen, czy nie?"

W Gródku Podolskim wielu katolików było przekonanych, że słowo katolik streszcza ich historię: katolicy, bo byli katowani. Prawosławni mieszkańcy zgadzali się z nimi co do źródłosłowu, ale utrzymywali, że to katolicy ich (prawosławnych) katowali, goniąc za nimi po polach (stąd Polacy), a przewodził tym katuszom św. Antoni. (Św. Antoni Padewski - Gródecki jest bowiem patronem tamtejszych „rzymokatolików”, a jego dawny obraz przetrwał radzieckie czasy, wyniesiony potajemnie, zanim wysadzono w powietrze kościół. Pozostaje dziś w głównym ołtarzu nowego kościoła, przyciągając tłumy w dniu odpustu.) W ten sposób ujawniają się sąsiedzkie animozje.

\section{Relacje kolonialne i déjà vu}

Wiadomo, że nie każde spotkanie jest przyjemne, ale przyjemność rozmowy nie jest w końcu ani jedynym, ani najważniejszym jej celem. Odbywaliśmy wycieczkę po Podolu, zorganizowaną przez przyjaciół z Winnickiego Uniwersytetu Pedagogicznego. W okolicach Humania zwiedzaliśmy wykopaliska i muzeum kultury trypolskiej, w którym obejrzeliśmy model domku z okrągłym oknem, z wyposażenia grobowca. Posłużył on regionalnym miłośnikom rodzimej prehistorii jako wzór architektoniczny: kilka domów miało podobne, okrągłe okna. Wieczorem zaproszono nas na ucztę pod rozłożystym drzewem; stół aż się uginał; zastawiły go obficie członkinie miejscowego zespołu śpiewaczego. Zapłonęło ognisko, kobiety pięknie śpiewały, syn gospodarza przygrywał na gitarze. Potem, w ciemnościach na drodze, gospodynie zaśpiewały nam jeszcze piosenkę na pożegnanie, a jedna z nich, zapytana o wrażenia, powiedziała, że zabrakło jej w naszym spotkaniu bliskości. Niespodziewanie któraś z nich, na oko sporo starsza ode mnie, dopadła mnie i, zanim się zorientowałam, o co chodzi, pocałowała mnie w rękę. Ten gest streszczał w sobie kolonialny habitus, zakonserwowany niczym w formalinie przez władzę radziecką. Kiedy byłam dziewczynką, całowałam moje babcie w rękę na powitanie, zarówno tę, która pochodziła ze wsi, jak i tę, która odebrała edukację na pensji dla dziewcząt i pracowała jako nauczycielka. Był to naturalny gest, który przyswoiłam w dzieciństwie, świadczący o hierarchii pokoleniowej, ale i o bliskości. W stosunku do rodziców już się go nie stosowało, a w ogóle ta forma zachowania społecznego zanikła dla mnie ostatecznie wraz z odejściem moich babek. Szok i wstyd, których doświadczyłam w związku z nim pod Humaniem, był niezwykle pouczający. Streszczał w sobie opasłe dzieło Daniela Beauvois (Beauvois 2005).

Czasami w trakcie badań na Wschodzie doświadczałam jednak mocnych wrażeń innego rodzaju. Miejsca, zapachy, krajobrazy, chociaż po raz pierwszy widziane i doświadczane, czasem smak potraw, budziły we mnie poruszające déjà $v u$, skojarzenia ze smakami dzieciństwa, z lekturami romantycznymi, których przecież w czasach PRL-u nie nie mogłam osadzić w kontekście. Nikt z mojej 
bliskiej rodziny nie pochodził z tamtych stron, a szkolna edukacja nie dostarczała bezpośredniej wiedzy na temat geografii i historii Litwy, Białorusi czy Ukrainy, jako odrębnych kulturowych bytów. Były to po prostu części rozległej zielonej przestrzeni na mapie, oznaczonej rozrzuconymi, wielkimi literami "ZSRR". (Z mapami w ogóle był w PRL-u problem: po prostu ich nie było, nawet polskich regionalnych; używaliśmy kserograficznych odbitek przedwojennych sztabówek, oznaczających wiele miejscowości, które już nie istniały.) Kiedy więc w trakcie wycieczki do Kamieńca Podolskiego znalazłam się w ruinach kościoła, w miejscowości o niewiele mi w pierwszej chwili mówiącej nazwie Окопи (Okopi), na wysokim brzegu Dniestru, który w tym miejscu tworzy malownicze zakola, nagle uświadomiłam sobie, że to Okopy Św. Trójcy, i że one naprawdę istnieją. Najwyraźniej do tej pory sądziłam, że Zygmunt Krasiński wymyślił sobie tę nazwę. Podobne doświadczenie stało się moim udziałem wiele lat później, kiedy ze znajomym proboszczem szukaliśmy po bezdrożach miejsca urodzin Ignacego Paderewskiego. Nagle kierowca wymienił nazwę rzeki, do której się zbliżaliśmy - Ikwa. „Bo tam, gdzie Ikwy srebrne fale płyną, byłem ja niegdyś jak Zośka dzieciną..." - wyświetliło mi się natychmiast w pamięci. Freud pisał o takich poruszających doświadczeniach, kiedy zapośredniczona, nabyta w czasach szkolnej edukacji wiedza, nagle powraca jako ucieleśniona, $\mathrm{w}$ bezpośrednim spotkaniu z rzeczywistym miejscem, w rzeczywistym czasie. Nabierają one w takich momentach magicznej głębi, niczym utkany emocjami pokoleń palimpsest. Właściwie każde miejsce, w którym zdarzyło mi się prowadzić badania etnograficzne, działało na mnie w taki sposób. Dlatego cenię Braudelowskie pojęcie długiego trwania form kulturowych, które jednak wciąż zmieniają znaczenia $\mathrm{w}$ zmieniających się kontekstach, niczym struktury tworzone przez kolorowe szkiełka w dziecięcych kalejdoskopach.

Zawstydzającym doświadczeniem, chociaż zupełnie inaczej niż poprzednio opisane, było powitanie w Widzach na Białorusi, jakie zgotowała nam pani Zofia Puszkowa. Polka, która ukończyła jeszcze przedwojenną polską szkołę powszechną, miała w miasteczku opinię osoby wykształconej i pisała listy do władz w imieniu lokalnej społeczności. Jej narzeczony zginął podobno w partyzantce. Pozostała samotna, ale - jako osoba niezwykle wrażliwa - podejmowała spontanicznie różne społeczne działania. Miała też wielki sentyment do wszystkiego, co kojarzyło jej się z Polską. Było dla niej oczywiste, że uroczyście przywita przyjeżdżających do miasteczka Polaków. Nasz autobus spóźnił się dwie godziny, bo zabrakło paliwa i kierowca musiał trochę odkupić od jednego z rzadko przejeżdżających kierowców. Była mroźna białoruska zima, może minus 16 stopni, zapadła już noc i ciemności panowały w centrum miasteczka Widze. Kiedy wysiedliśmy, drobna kobieca postać podbiegła do nas, wyprężyła się na baczność i zaczęła recytować uroczyste słowa powitania głosem drążącym z wyziębienia i wzruszenia. Zupełnie na to nie zasługiwaliśmy.

Te teatralne powitania i pożegnania rodaków przeszły do naszej lokalnej mitologii. Kiedyś profesor Lech Mróz, który zapoczątkował nasze tzw. badania wschodnie, wracał z Wileńszczyzny - jak zwykle nocnym autobusem, z długim, 
wyczerpującym postojem na granicy, i - jak zwykle - obarczony był licznymi podarkami, które mu wręczył na odjezdnym przyjaciel spod Wilna. Może to były palmy wielkanocne, a może kosz z Suderwy, zapewne jakieś przysmaki. Przyjaciel ów zadzwonił potem do żony profesora i, zaniepokojony o dobrostan obciążonego ponad miarę Mroza, zapytał swoją przeciągłą, kresową polszczyzną: „A kto przywita?", sugerując, że mężowi trzeba by ponieść bagaże.

Czasami fragmenty rozmów czy obserwacje powracają nagle po latach w pamięci i doświadczam żalu, że nie byłam wystarczająco czujna i uważna, żeby podążyć ich tropem. Do takich zagubionych wątków zaliczam wspomnienie pewnej katoliczki z wioski pod Hwardijskiem (dawniej Felsztyn) na Podolu, z drugiej połowy lat 90. Wspominała swoje dzieciństwo i niedzielne wyprawy do Gródka Podolskiego, gdzie jedyny wówczas w promieniu kilkuset kilometrów ksiądz odprawiał msze w cmentarnej kaplicy. Nie było zegara, opowiadała, ale matka nocą wychodziła przed dom i patrzyła w gwiazdy, z których układu potrafiła się zorientować, czy już czas wyruszać. Budziła dzieci, kiedy jeszcze było całkiem ciemno, żeby zdążyły dotrzeć na czas na mszę. Chłopskie rachuby czasu, sposoby nadawania mu znaczeń, zmieniające się radykalnie w procesie transformacji, to jeden z wielkich tematów, zaledwie zaczętych w moich studiach "przemiany światów”.

Innym intrygującym tematem był czakram w kolegiacie „rzymokatolickiej” w Żółkwi, (miejscu pochówku m.in. hetmana Żółkiewskiego i królewiczów Sobieskich), a dokładnie w punkcie, gdzie zbiegają się centralnie linie mozaiki, tworząc krzyż na posadzce. Pracowała tam w początkach naszego wieku grupa studencka, którą opiekowała się moja koleżanka, a ja odwiedziłam ich tylko na kilka dni. Sądziłam, że pomysł czakramu zachodnioukraińskie miasteczko zapożyczyło z globalnego New Age'u. Kiedy jednak leciwa rozmówczyni w pobliskiej wiosce, znana $z$ leczenia modlitwą, wyjawiła niepytana, że modlitwa w tym właśnie miejscu, a zwłaszcza w czasie Podniesienia, jest niezwykle skuteczna, uświadomiła mi, że to przypadek glokalizacji. Miejsca splatania się lokalnych praktyk wpisanych w podzielane przez małe społeczności znaczenia z globalnymi tendencjami i ich wzajemne projekcje wydają mi się wyjątkowo pociągającym obszarem badań. W tym przypadku czakram połączył specyficzną ukraińską wieloznaczność pojęcia energii (czym zajmują się już od pewnego czasu moje koleżanki): mistyczną, wpisaną w prawosławną teologię boskich energii Grzegorza Palamasa, i zarazem materialną, z tradycją miejsc „namodlonych” i katolickim kultem Eucharystii. Przenikają się odmienne style chrześcijaństwa i globalne trendy kultury popularnej.

Podobne zjawisko obserwowaliśmy na Podolu, w związku ze zbliżającym się końcem świata rzekomo zapowiadanym przez kalendarz Majów na grudzień 2012 r. Majowie wierzyli, że przed naszym światem istniały jeszcze trzy wcześniejsze, co przypomina wizję dziejów odnotowaną przez nas w latach 80. i 90. ubiegłego wieku: po świecie Boga Ojca następuje świat Boga Syna (to nasz, środkowy), po nim zaś nastąpi świat Boga Ducha Świętego. Jednak światy (w specyficznym znaczeniu czasu, przestrzeni i narodu) rozdzielają kataklizmy, niosąc ludziom zagładę. Mieszkańcy Murafy, sposobiąc się do przetrwania 
Apokalipsy, wykupowali masowo konserwy, zapałki i świece, których nagle zabrakło w miejscowych sklepikach. Nie pomogło wyśmianie tych praktyk przez proboszcza w kazaniu podczas sumy; pożywka medialna, powiązana z działalnością Fenomenu 2012, weszła w rezonans z tradycją, a także z powszechnym poczuciem niepewności w obliczu transformacji i nieustającego procesu zmian. Jeden z rozmówców, gorliwy czytelnik Biblii Tysiąclecia, którą nosił ze sobą plastikowej torbie, wyjaśnił mi, że Antychryst, według przepowiedni, miał się urodzić w pokoleniu Dana, i że to już nastąpiło. W gruncie rzeczy Murafianie mieli rację: stary świat się kończył, a ja znowu nauczyłam się czegoś o Biblii. Plemię Dana, jako jedyne z pokoleń Izraela, nie zostało bowiem wymienione w Księdze Apokalipsy wśród tych, którzy zostali opieczętowani, czyli - wśród zbawionych, a o tym, że Antychryst z niego ma pochodzić, pisał Ireneusz z Lyonu w Adversus haereses. Mój rozmówca słyszał jednak o tym od swojej niepiśmiennej matki.

Tę opowieść mogłabym snuć dalej, bo w miarę jak przywołuję wspomnienia kolejnych badań etnograficznych, powraca ich coraz więcej. Laboratoria pomagają w gromadzeniu wiedzy wynikającej z doświadczeń, wielozmysłowej, dalekiej od teoretycznej sofistyki, zarazem inicjującej refleksje teoretyczne. W grupie kultywujemy raczej współpracę niż konkurencję: transkrypcje dobrych wywiadów tworzą wspólny zasób źródłowy. Wiadomo przecież, że odpowiedzi uzyskuje się wówczas, kiedy nie pyta się wprost albo kiedy pytanie dotyczy czegoś innego; najczęściej przez przypadek. Wśród zmieniających się teorii i mód, a nawet nazw dyscypliny, praktyka etnografii pozostaje jedynym łącznikiem moich doświadczeń z czasów studenckich z obecną antropologią społeczno-kulturową, łącznikiem światów moich, akademickiego i osobistego, światów studentów i światów naszych rozmówców. Komunikacja ma bowiem charakter dwupoziomowy.

Prowadzę kolejne Laboratorium. Mieliśmy jechać do Szarogrodu na Podolu, wszystko było przygotowane, studenci uczyli się ukraińskiego. Projekt upadł w związku z pandemią. Zmieniliśmy teren badań na Trzebiatów w województwie zachodniopomorskim, miasto słynnej słonicy Hansken, „muzy Rembrandta”, z wyrazistą grupą ukraińskich mieszkańców, reprezentantów przesiedleńców w akcji W. Jeszcze raz spróbujmy.

\section{Literatura}

Beauvois, D. (2005). Trójkąt ukraiński. Szlachta, carat i lud na Wotyniu, Podolu i Kijowszczyźnie 1793-1914. Przeł. K. Rutkowski. Lublin: Wydawnictwo Uniwersytetu Marii Curie-Skłodowskiej.

Gadamer, H.G. (1980). Niezdolność do rozmowy. Przeł. B. Baran. Znak, 309 (3), 369-376.

Hastrup, K. (2008). Droga do antropologii. Między doświadczeniem a teorią. Przeł. E. Klekot. Kraków: Wydawnictwo Uniwersytetu Jagiellońskiego.

Herzfeld, M. (2004). Antropologia. Praktykowanie teorii w kulturze i społeczeństwie. Przeł. M.M. Piechaczek. Kraków: Wydawnictwo Uniwersytetu Jagiellońskiego.

Zandberg, A. (2012). „Villages ... Reek of Ether Vapours”: Ether Drinking in Silesia before 1939. Medical History, 54(3), 387-396. 


\section{SUMMARY}

Images from fieldwork or the oneiric reminiscences of Ethnography Labs

I present multi-sensory memories from my field research that keep imbuing encounters with people and other beings with specific meaning. Such memories combine dialogues with pictures, sounds, smells and tastes, and can be conceived of as inspiration underlying ethnographic and anthropological research. In this context, I reflect on the method of teaching skills of ethnographic field research within "Ethnographic Laboratories", a module introduced as part of the teaching curriculum at the Institute of Ethnology and Cultural Anthropology, University of Warsaw.

Keywords: Fieldwork, ethnographic multi-sensory experience, teaching methods, Ethnographic Laboratory 